\title{
Store-refilling involves both L-type calcium channels and reverse-mode sodium- calcium exchange in airway smooth muscle
}

\author{
S. Hirota and L.J. Janssen
}

ABSTRACT: The aim of the present study was to examine the relative contributions to storerefilling of the two following voltage-regulated calcium ion influx pathways: 1) L-type-Ca ${ }^{2+}$ channels; and 2) the reverse-mode of the sodium-calcium exchanger (NCX).

Successive acetylcholine-induced contractions, triggered in bovine tracheal smooth muscle strips, were measured to determine the effect of intervention on contractions as an indication of the extent of store-refilling.

Pre-treating the tissues with cromakalim significantly reduced the magnitude of successive contractions. Zero- $\mathrm{Ca}^{2+}$ bathing media abolished the contractions, an effect that was completely reversed upon reintroduction of $\mathrm{Ca}^{2+}$. Inhibition of L-type $\mathrm{Ca}^{2+}$ channels, with nifedipine, significantly reduced the magnitude of the contractions. Similarly, inhibition of the reverse-mode of the NCX, with KB-R7943, significantly reduced the magnitude of the contractions. However, neither nifedipine nor KB-R7943 alone reduced contractions to the same extent as observed under zero- $\mathrm{Ca}^{2+}$ conditions. Concurrent treatment with nifedipine and KB-R7943 almost abolished successive contractions. Furthermore, concurrent treatment with nifedipine and zero- $\mathrm{Na}^{+}$bathing media displayed a significantly greater effect than nifedipine alone. Probing the expression of NCX1 isoforms by Western blotting revealed the presence of three bands of 160, 120 and $110 \mathrm{kDa}$. The 120- and 110-kDa bands were identified as variably spliced NCX isoforms, NCX1.1 and NCX1.3, respectively.

Taken together, these data suggest that influx of calcium ions through both L-type calcium channels and the reverse-mode of the sodium-calcium exchanger is necessary for complete store-refilling in airway smooth muscle.

KEYWORDS: Airway smooth muscle, calcium-handling, L-type calcium channel, membrane depolarisation, reverse-mode sodium-calcium exchanger, sarcoplasmic reticulum

ontraction of airway smooth muscle (ASM) is mediated in large part through agonist-induced mobilisation of $\mathrm{Ca}^{2+}$ from the sarcoplasmic reticulum (SR). Following $\mathrm{Ca}^{2+}$-mobilisation, mechanisms must exist to reduce intracellular $\mathrm{Ca}^{2+}$ levels, leading to relaxation. Cytosolic $\mathrm{Ca}^{2+}$ can be sequestered into the SR through the active pumping of the sarco/ endoplasmic reticulum calcium-adenosine triphosphatase (ATPase) for subsequent mobilisation or extruded to the extracellular domain by the plasma membrane calcium-ATPase and the forward-mode of the sodium-calcium exchanger (NCX). The $\mathrm{Ca}^{2+}$ deficit resulting from the extrusion of $\mathrm{Ca}^{2+}$ from the cell must be reversed in order for cells to store adequate $\mathrm{Ca}^{2+}$ for subsequent mobilisation and contraction.
Indeed, agonist stimulation can activate $\mathrm{Ca}^{2+}$ influx pathways that contribute to the overall intracellular $\mathrm{Ca}^{2+}$ pool. Mobilisation of $\mathrm{Ca}^{2+}$ from the SR can activate depolarising membrane chlorine ion currents that trigger voltage-dependent $\mathrm{Ca}^{2+}$ influx [1-3]. L-type $\mathrm{Ca}^{2+}$ channels have been viewed as the primary conduit for voltagedependent $\mathrm{Ca}^{2+}$ influx, and there are several reports that these appear to play a role in $\mathrm{Ca}^{2+}$ store-refilling [4-6], although inhibition of this pathway did not completely mimic the effect of complete removal of external $\mathrm{Ca}^{2+} . \mathrm{Ca}^{2+}$ influx via the reverse-mode of the NCX is also driven by membrane depolarisation, in conjunction with increased intracellular $\mathrm{Na}^{+}$levels mediated by the gating of store-operated nonselective cation channels (NSCCs) [7-11, reviewed in 12]. An

\section{AFFILIATIONS}

Firestone Institute for Respiratory Health, St. Joseph's Healthcare and Dept of Medicine, McMaster University, Hamilton, ON, Canada

\section{CORRESPONDENCE}

L.J. Janssen

L-314

St. Joseph's Healthcare

50 Charlton Ave. East

Hamilton

ON

Canada L8N 4A6

Fax: 19055406510

E-mail: janssenl@mcmaster.ca

Received:

January 222007

Accepted after revision:

March 292007

\section{SUPPORT STATEMENT}

L.J. Janssen was supported by Career Awards from the Canadian Institutes of Health Research (Ottawa, ON, Canada) and S. Hirora by the Natural Sciences and Engineering Research Council of Canada (Ottawa ON, Canada). Operating grants were also received from the Canadian Institutes of Health Research and Ontario Thoracic Society (Toronto ON, Canada)

STATEMENT OF INTEREST None declared. 
additional contribution of reverse-mode NCX activity to partial refilling of the internal store in ASM following agonist stimulation has recently been documented [13]. Finally, a membrane conductance that is activated upon store depletion, and which might play a role in store refilling, has also been described [14]. The relative contributions of the two voltagedependent $\mathrm{Ca}^{2+}$-influx pathways (the reverse-mode of the NCX and L-type $\mathrm{Ca}^{2+}$-channels) and the voltage-independent receptor/store-operated cation channel (ROC/SOC) current to store refilling in ASM are still the subject of much investigation and debate.

The aim of the present study was to address this question by comparing the effects of selective blockers of the reverse-mode of the NCX (KB-R7943) and/or L-type $\mathrm{Ca}^{2+}$-channels (nifedipine) with those of suppressing voltage-dependent mechanisms in general using a potassium channel opener (cromakalim) and suppressing $\mathrm{Ca}^{2+}$ influx in general by omitting $\mathrm{Ca}^{2+}$ from the bathing medium.

\section{MATERIALS AND METHODS}

\section{Animals}

All experimental procedures were approved by the McMaster University Animal Care Committee (McMaster University, Hamilton, ON, Canada) and conformed to the guidelines set out by the Canadian Council on Animal Care (Ottawa, ON, Canada). Tracheae were obtained from cows (136-454 kg) euthanised at the local abattoir and transported to the laboratory in ice-cold modified Krebs buffer $(116 \mathrm{mM} \mathrm{NaCl}$, $4.6 \mathrm{mM} \mathrm{KCl}, 1.2 \mathrm{mM} \mathrm{MgSO}_{4}, 2.5 \mathrm{mM} \quad \mathrm{CaCl}_{2}, 1.3 \mathrm{mM}$ $\mathrm{NaH}_{2} \mathrm{PO}_{4}, 23 \mathrm{mM} \mathrm{NaHCO}_{3}, 11 \mathrm{mM}$ D-glucose, $0.01 \mathrm{mM}$ indomethacin, $0.0001 \mathrm{mM}$ propranolol and $0.1 \mathrm{mM} N^{\omega}$-nitroL-arginine (L-NNA), saturated with $95 \%$ oxygen $/ 5 \%$ carbon dioxide to maintain $\mathrm{pH}$ at 7.4). Upon receipt of a trachea, the epithelium was removed and tracheal strips $(\sim 2-3 \mathrm{~mm}$ wide and $\sim 10 \mathrm{~mm}$ long) were excised and used immediately or stored at $4{ }^{\circ} \mathrm{C}$ for up to $48 \mathrm{~h}$.

\section{Study design}

In order to examine the extent of store-refilling in smooth muscle, successive agonist-induced contractions of isolated ASM strips were measured using a standard organ bath preparation. Interventions aimed at inhibiting $\mathrm{Ca}^{2+}$ influx pathways (using $\mathrm{Ca}^{2+}$-free Krebs buffer, composed as modified Krebs buffer but with the omission of $\mathrm{CaCl}_{2}$ and addition of $1 \mathrm{mM}$ ethyleneglycol bis-(2-aminoethylether)- $N, N, N^{\prime} N^{\prime}$-tetraacetic acid (EGTA)), namely the reverse-mode of the NCX (using KB-R7943 (0.1 M in dimethylsulphoxide diluted in Krebs buffer as appropriate) and Zero- $\mathrm{Na}^{+}$Krebs buffer, composed as modified Krebs buffer but with $\mathrm{N}$-methyl-Dglucamine in place of $\mathrm{NaCl}$ and $\mathrm{KH}_{2} \mathrm{PO}_{4}$ and $\mathrm{KHCO}_{3}$ instead of $\mathrm{NaH}_{2} \mathrm{PO}_{4}$ and $\mathrm{NaHCO}_{3}$, with the $\mathrm{pH}$ adjusted to 7.4 using $5 \mathrm{~N} \mathrm{HCl}$ and saturated with $95 \%$ oxygen/5\% carbon dioxide to maintain this $\mathrm{pH}$ ) and L-type $\mathrm{Ca}^{2+}$ channels (using $0.1 \mathrm{M}$ nifedipine in ethanol diluted in Krebs buffer as appropriate), were employed after obtaining a control acetylcholine (Ach) response (using $0.1 \mathrm{M} \mathrm{ACh}$ in distilled deionised water diluted in Krebs buffer as appropriate), and the magnitude of each subsequent contractile response was normalised to this control response in order to determine what effect inhibition of various $\mathrm{Ca}^{2+}$ influx pathways might have on store-refilling, reflected by a reduction in successive contractile responses.

\section{Methods}

Organ bath studies

Contractile studies were performed as described previously by HiROTA and co-workers [13, 15]. Briefly, ASM strips were mounted in 4-mL organ baths, using silk thread to anchor one end of the strip and attach the other to a Grass FT.03 force transducer (Grass Technologies, Longueuil, QC, Canada). Isometric tension was recorded on-line using the DigiMed System Integrator program (MicroMed, Louisville, KY, USA). Tissues were bathed in modified Krebs buffer saturated with $95 \%$ oxygen $/ 5 \%$ carbon dioxide, and heated to $37^{\circ} \mathrm{C}$. During the 1-h equilibration, tissues were repeatedly washed with modified Krebs buffer and tested for viability using $60 \mathrm{mM}$ $\mathrm{KCl}$. The $\mathrm{KCl}$ was then washed out, and tissues were allowed to recover before experiments were conducted. Successive ACh-induced contractions were triggered using the concentration of ACh previously found to be half-maximal $\left(3 \times 10^{-7} \mathrm{M}\right)$ $[13,15]$. Each tissue strip underwent only one intervention.

\section{Western blot assay for NCX isoform 1}

Tissues were homogenised in ice-cold magnesium lysis buffer (50 mM tris(hydroxymethyl)aminomethane (Tris) $-\mathrm{HCl}$ (pH 7.5), $0.1 \mathrm{mM}$ EDTA, $0.1 \mathrm{mM}$ EGTA, $750 \mathrm{mM} \mathrm{NaCl}, 5 \%$ Igepal CA-630 (Sigma-Aldrich Canada, Oakville, ON, Canada), $50 \mathrm{mM} \mathrm{MgCl}$, $10 \%$ glycerol, $10 \mu \mathrm{g} \cdot \mathrm{mL}^{-1}$ aprotinin, $10 \mu \mathrm{g} \cdot \mathrm{mL}^{-1}$ leupeptin, $1 \mathrm{mM}$ phenylmethylsulphonyl fluoride, $1 \mathrm{mM} 4-(2-$ aminoethyl)-benzenesulphonyl fluoride and $2 \mathrm{mM}$ sodium orthovanadate), total protein content determined (Bradford method) and protein concentration adjusted to $100 \mu \mathrm{g} \cdot \mathrm{mL}^{-1}$ using $2 \times$ Laemmli sample/loading buffer $(62.5 \mathrm{mM}$ Tris- $\mathrm{HCl}$ ( $\mathrm{pH}$ 6.8), 2\% sodium dodecylsulphate, 10\% glycerol, $50 \mathrm{mM}$ dithiothreitol, $0.1 \%$ 2-mercaptoethanol and $0.01 \%$ bromophenol blue). Samples were boiled for $5 \mathrm{~min}$ in this buffer, subjected to electrophoresis and then transferred to nitrocellulose membrane (blocked with $5 \%$ bovine serum albumin and $5 \%$ skimmed milk in Tris-buffered saline). NCX isoform 1 (NCX1) was visualised using a polyclonal rabbit primary antibody directed against NCX1 (Chemicon, Billerica, MA, USA) and a mouse anti-immunoglobulin $G$ secondary antibody preparation (Upstate Biotechnology, Waltham, MA, USA).

\section{Analysis}

The effect of interventions targeting $\mathrm{Ca}^{2+}$ influx pathways is expressed as the percentage change from within-tissue control ACh responses $\left(3 \times 10^{-7} \mathrm{M}\right)$. All responses are reported as mean \pm SEM. Comparisons were performed using an unpaired t-test (for single pairwise comparisons) or two-way ANOVA (for multiple comparisons of means) followed by the appropriate post hoc test (Newman-Keuls). A p-value of $<0.05$ was considered significant.

\section{RESULTS}

In order to probe the relative involvement of $\mathrm{Ca}^{2+}$ influx pathways in store-refilling in ASM, a standard organ bath preparation was employed. Using this technique, successive agonist-induced contractions were triggered using $\mathrm{ACh}$ $\left(3 \times 10^{-7} \mathrm{M}\right)$. Reproducible contractions could be triggered at 15-min intervals (fig. 1). Removal of $\mathrm{Ca}^{2+}$ from the bathing 
a)

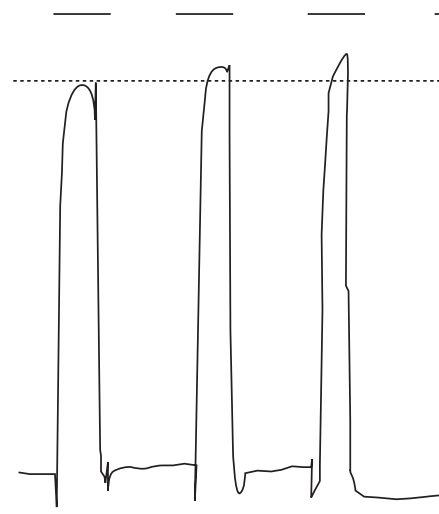

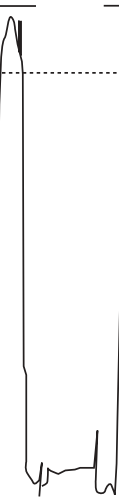
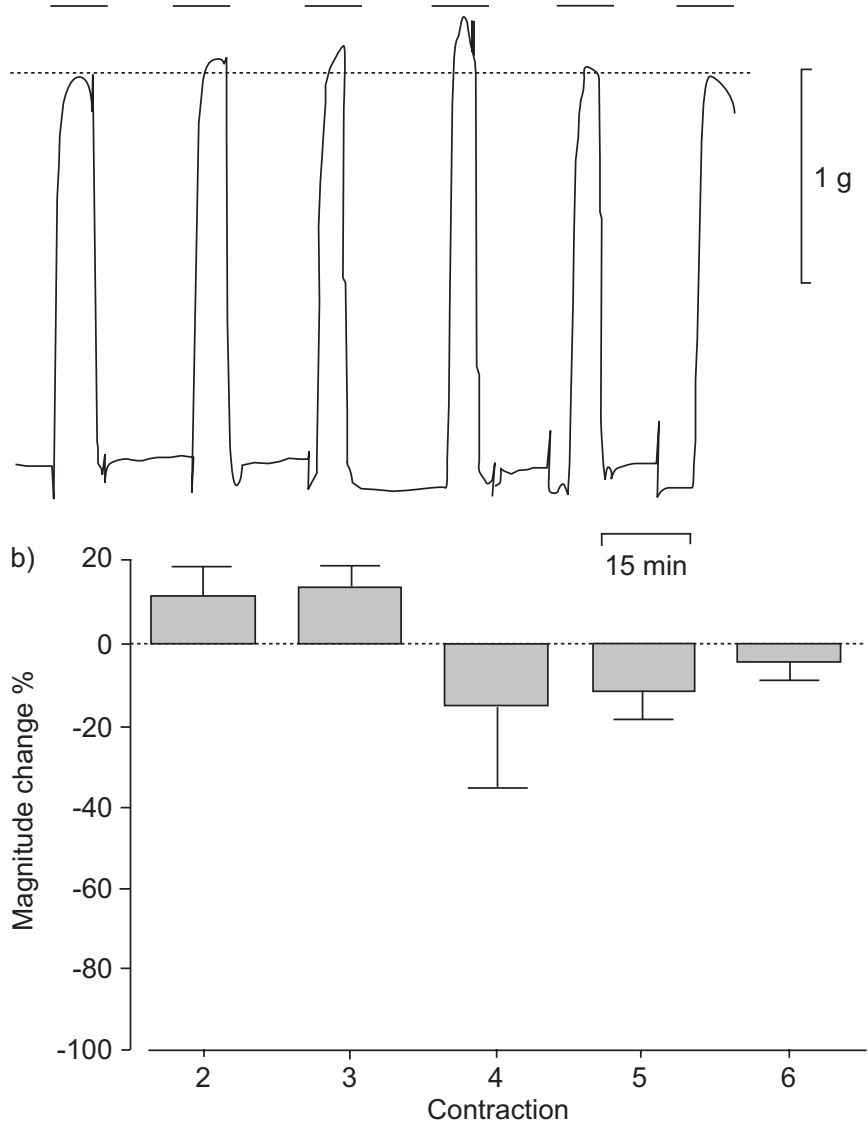

FIGURE 1. a) Representative $3 \times 10^{-7} \mathrm{M}$ acetylcholine (ACh; horizontal bars)induced contractions of bovine airway smooth muscle $(n=10)$........ Magnitude of first contraction. b) Mean change in peak magnitude of the ACh-induced contractions. Data are presented as mean \pm SEM.

solution led to a rapid and complete but reversible reduction in the magnitude of the agonist-induced contractions (fig. 2).

In order to investigate the pathways through which $\mathrm{Ca}^{2+}$ enters the cell on its way to the SR, a series of pharmacological interventions were employed. First, successive contractions were evoked in the presence of cromakalim $(30 \mu \mathrm{M}(0.01 \mathrm{M}$ in distilled deionised water diluted in Krebs buffer as appropriate)), a compound that increases the open probability of adenosine triphosphate (ATP)-dependent potassium channels $\left(K_{\text {ATP }}\right)$ [6, reviewed in 16]. Activation of $K_{\text {ATP }}$ interferes with membrane depolarisation, thereby inhibiting voltage-dependent downstream events (e.g. the reverse-mode of the NCX and L-type $\mathrm{Ca}^{2+}$ channels). Cromakalim treatment led to a significant reduction in the magnitude of successive AChinduced contractions (figs 3a and c). This effect was abolished by concurrent treatment with glibenclamide

Since hyperpolarisation of the membrane reduced the magnitude of successive contractions, an approach that targeted the two downstream $\mathrm{Ca}^{2+}$ influx pathways that can be activated by membrane depolarisation was employed to determine their relative contribution to store-refilling. In order to examine the contribution of the NCX, tissues were treated with KB-R7943 a)
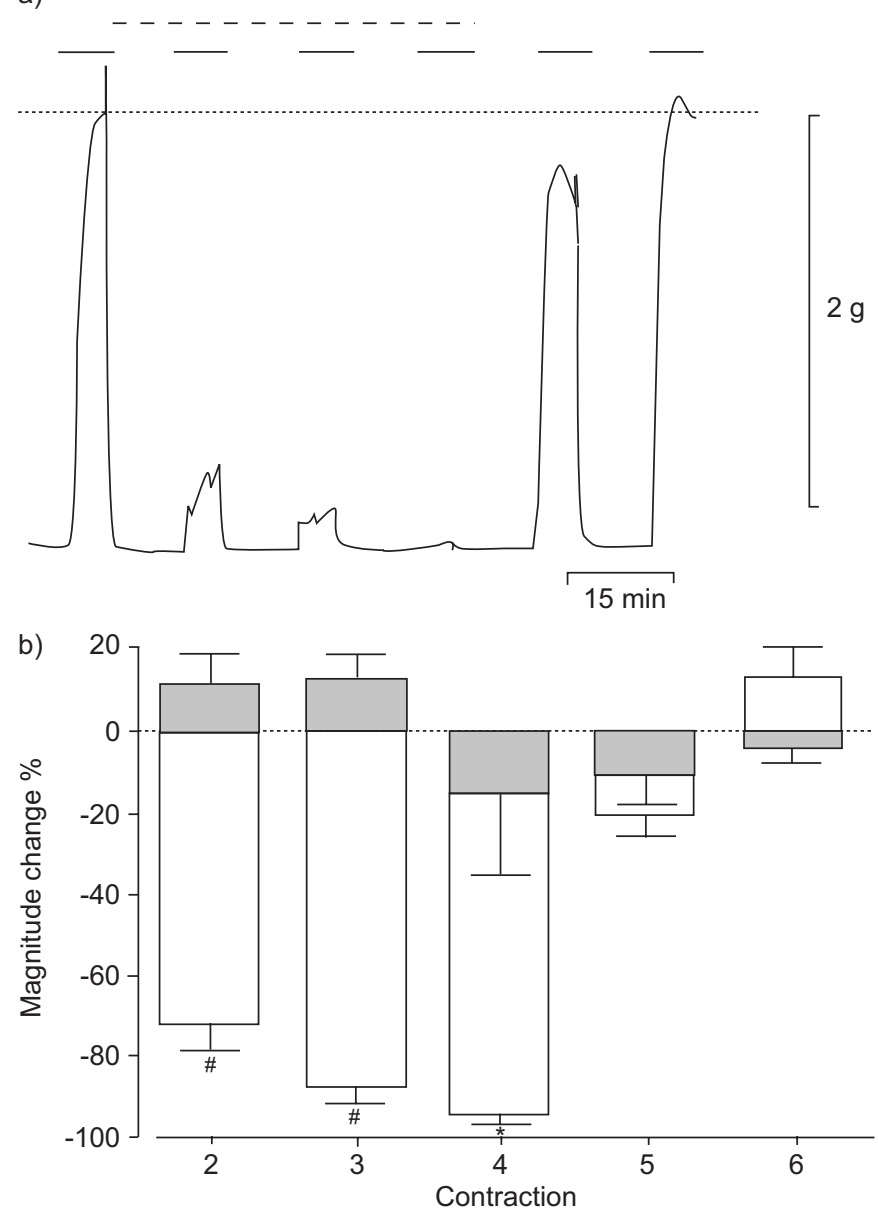

FIGURE 2. a) Representative $3 \times 10^{-7} \mathrm{M}$ acetylcholine (ACh; horizontal bars)induced contractions of bovine airway smooth muscle (ASM) before, during and after removal of extracellular calcium ions $(n=5)$. At the end of the zero- $\mathrm{Ca}^{2+}$ period (- - -), the ASM was washed with standard $\mathrm{Ca}^{2+}$-containing buffer. ....... Magnitude of first contraction. b) Mean change in peak magnitude of these AChinduced contractions $(\square)$ compared with control responses $(\square ; n=10)$. Data are presented as mean \pm SEM. *: $p<0.05 ; *: p<0.005$.

(10 or $20 \mu \mathrm{M}$ ), a selective inhibitor of the reverse-mode (i.e. $\mathrm{Ca}^{2+}$ influx mode) of the NCX [17-21]. Both 10 and $20 \mu \mathrm{M} \mathrm{KB}-$ R7943 significantly reduced successive ACh-induced contractions by $\sim 50 \%$ (fig. 4). Similarly, successive responses from tissues treated with nifedipine $(1 \mu \mathrm{M})$, a selective inhibitor of L-type $\mathrm{Ca}^{2+}$ channels, were significantly reduced by $\sim 50 \%$ (fig. 5). Thus neither KB-R7943 nor nifedipine alone reduced successive contractions to the same extent as observed when tissues were exposed to zero-Ca ${ }^{2+}$ conditions (fig. 6). However, concurrent treatment with KB-R7943 $(10$ or $20 \mu \mathrm{M})$ and nifedipine $(1 \mu \mathrm{M})$ effectively abolished successive AChinduced contractions (fig. 7) to the extent observed during zero-Ca ${ }^{2+}$ treatment (fig. 8).

In addition to pharmacological inhibition of the NCX, an ionic substitution protocol was employed to generate $\mathrm{Na}^{+}$-free Krebs buffer. It has previously been shown that long-term bathing in zero- $\mathrm{Na}^{+}$buffer reduces refilling through inhibition of the reverse-mode of the NCX [13]. Treating tissues with nifedipine 
a)
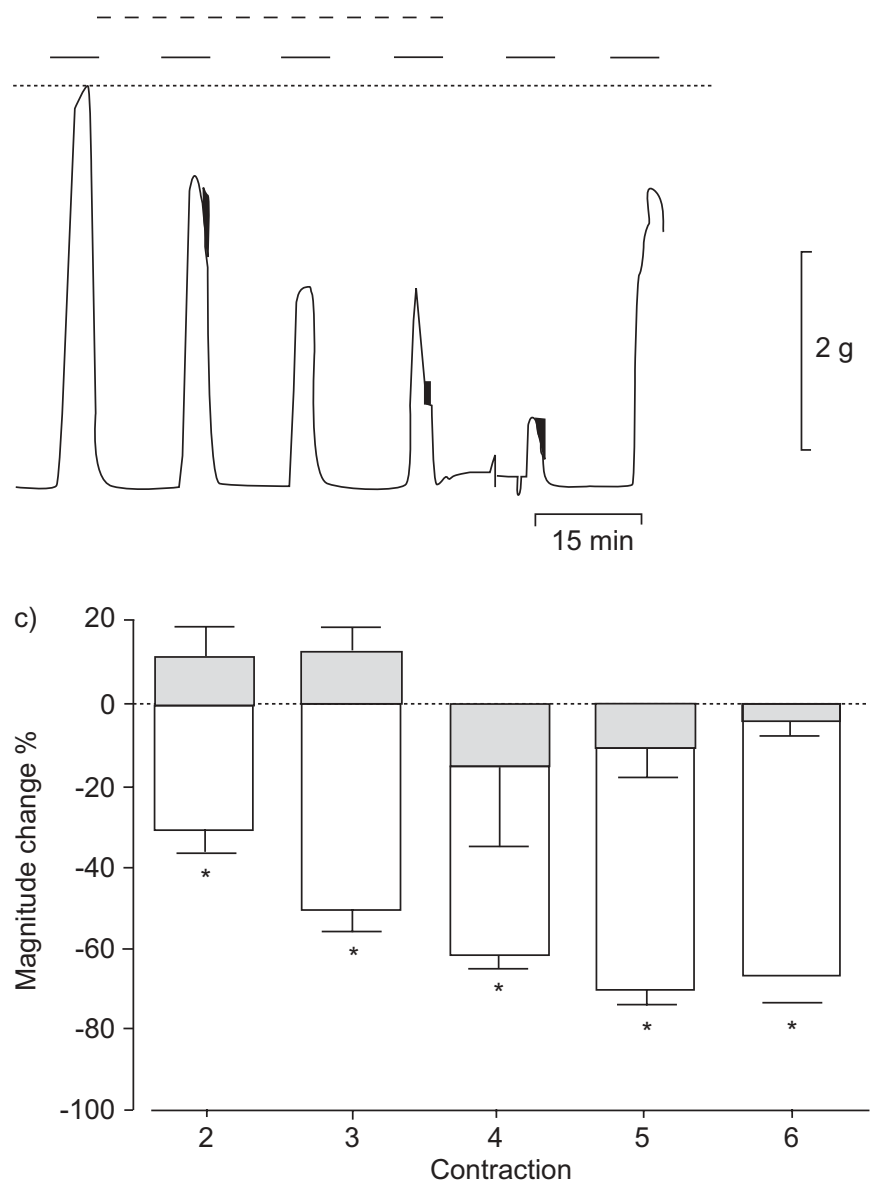

b)

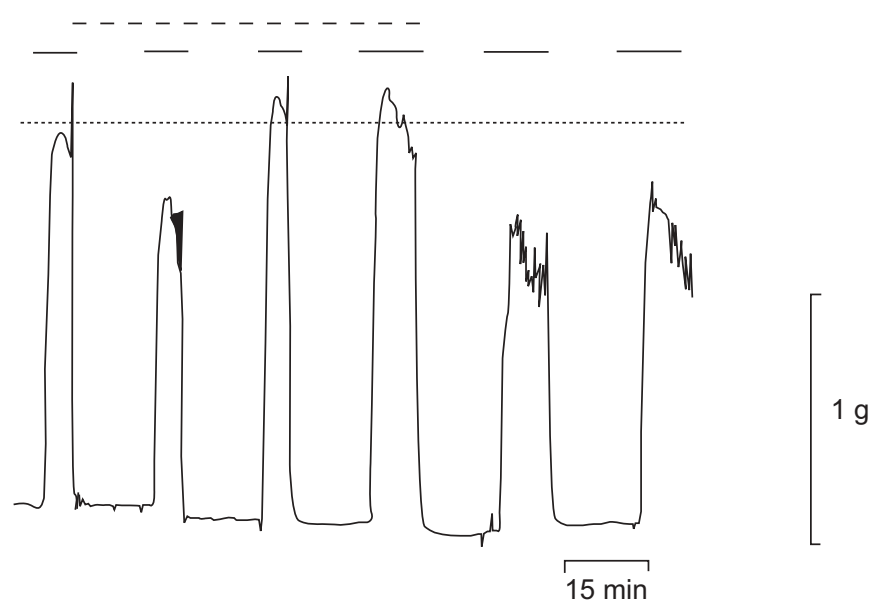

d)

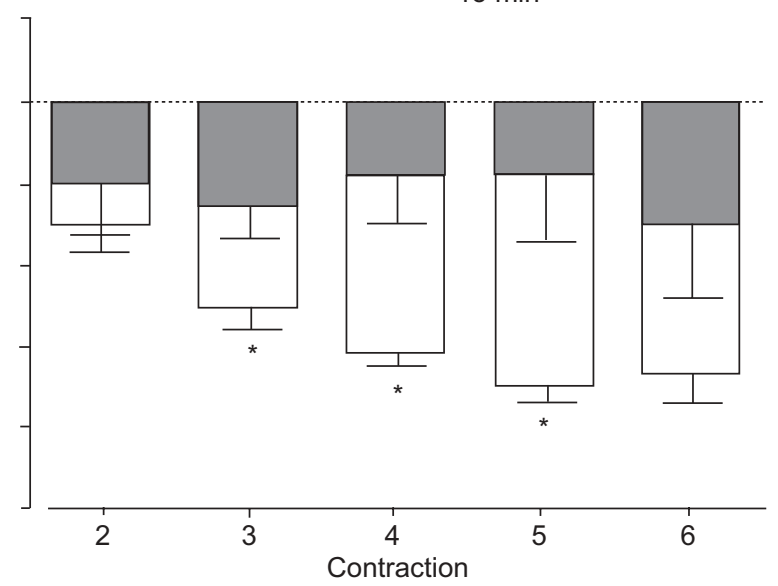

FIGURE 3. Representative $3 \times 10^{-7} \mathrm{M}$ acetylcholine (ACh; horizontal bars)-induced contractions of bovine airway smooth muscle (ASM) before, during and after exposure to $30 \mu \mathrm{M}$ cromakalim: a) alone $(\mathrm{n}=12)$ and $\mathrm{b})$ in combination with $10 \mu \mathrm{M}$ glibenclamide $(\mathrm{n}=5)$. After exposure $(---)$, the ASM was washed with standard Ca ${ }^{2+}$ containing buffer. .......: Magnitude of first contraction. c, d) Mean change in peak magnitude of these ACh-induced contractions ( $\square$ : cromakalim; $\square$ : cromakalim plus glibenclamide) compared with control responses $(\square ; n=10)$. Data are presented as mean \pm SEM. * : $p<0.05$.

$(1 \mu \mathrm{M})$ in the absence of extracellular $\mathrm{Na}^{+}$significantly reduced successive ACh-induced contractions (figs 9a and b). Furthermore, removal of extracellular $\mathrm{Na}^{+}$during nifedipine treatment led to a significantly greater reduction in responses than observed when tissues were treated with nifedipine alone (fig. 9c). However, this treatment did not reduce contractions to the extent observed under zero- $\mathrm{Ca}^{2+}$ conditions (fig. 9d).

In addition to examining the functional importance of the NCX in store-refilling, NCX1 expression was examined in protein isolates from bovine tracheal smooth muscle. In tracheal strips from six different animals, Western blot analysis revealed the existence of three predominant proteins of 160, 120 and $110 \mathrm{kDa}$ (fig. 10).

\section{DISCUSSION}

The aim of the present study was to examine the relative roles of two $\mathrm{Ca}^{2+}$ influx pathways, both regulated by membrane potential, in the process of refilling the SR. A role for the NCX in store-refilling has recently been described, whereby its reverse-mode provides substantial $\mathrm{Ca}^{2+}$ influx for the refilling of the SR following agonist-induced $\mathrm{Ca}^{2+}$ mobilisation [13]. In this earlier report, inhibition of the reverse-mode of the NCX, through removal of extracellular $\mathrm{Na}^{+}$or treatment with KBR7943, reduced the magnitude of successive agonist-induced contractions. This was associated with a reduction in agonistinduced $\mathrm{Ca}^{2+}$ mobilisation, measured via $\mathrm{Ca}^{2+}$ fluorescence imaging, in freshly isolated ASM cells. In addition to the reverse-mode of the NCX, others have reported that voltagedependent $\mathrm{Ca}^{2+}$ influx, via activation of L-type $\mathrm{Ca}^{2+}$ channels, plays a significant role in store-refilling [4-6]. Interestingly, these conclusions have often been based on experimental protocols designed to manipulate membrane potential in order to alter $\mathrm{Ca}^{2+}$ influx via L-type $\mathrm{Ca}^{2+}$ channels. However, the reverse-mode of the NCX is also driven by membrane depolarisation, in conjunction with local increases in intracellular $\mathrm{Na}^{+}$concentration that can be triggered through gating of NSCCs [7-11], reviewed in [12]. The previous studies examining voltage-dependent $\mathrm{Ca}^{2+}$ influx have overlooked the role of the reverse-mode of the NCX, attributing influx entirely to Ltype $\mathrm{Ca}^{2+}$ channels.

Influx pathways activated during agonist-induced contraction must exist to provide the cell with an intracellular $\mathrm{Ca}^{2+}$ pool 

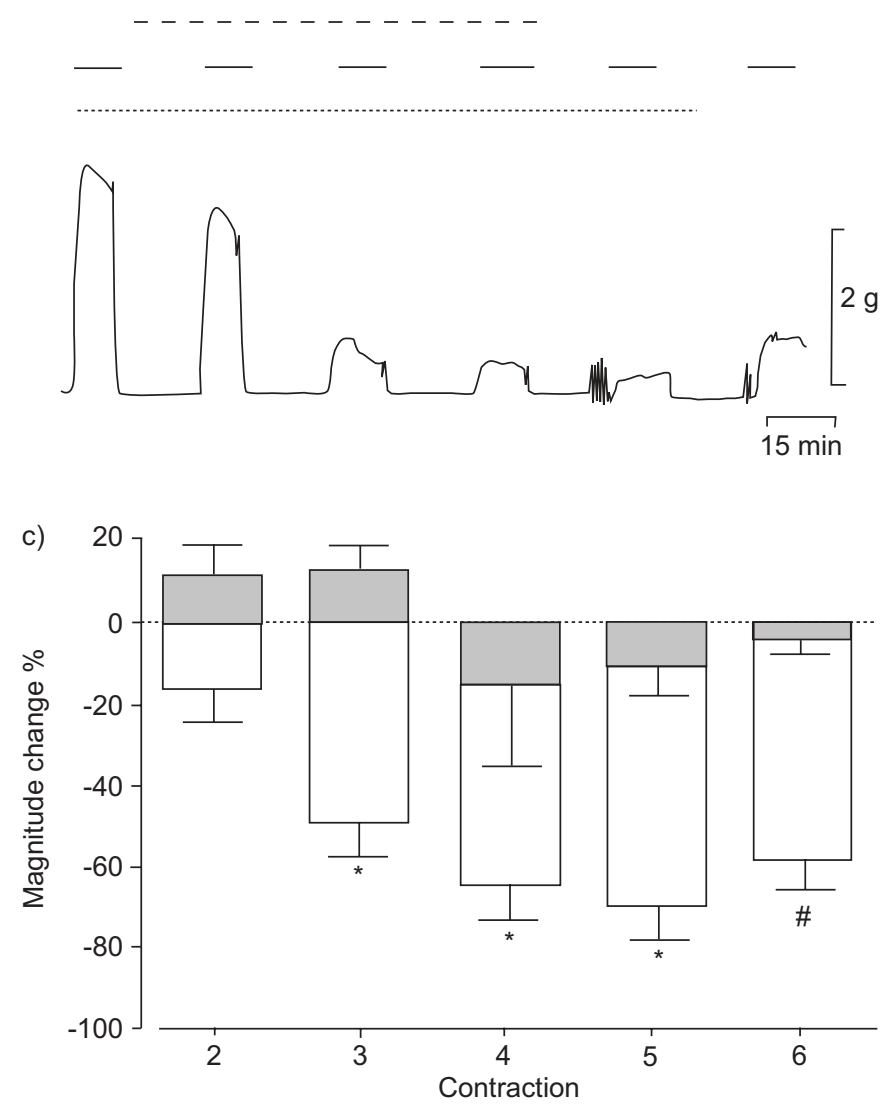

b)

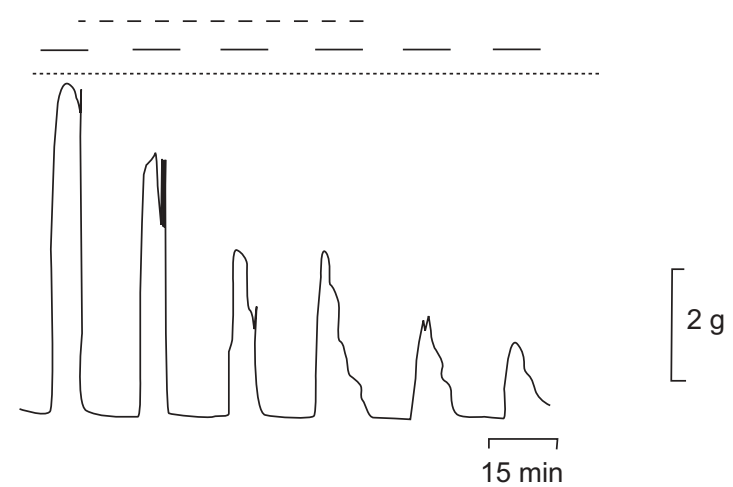

d)

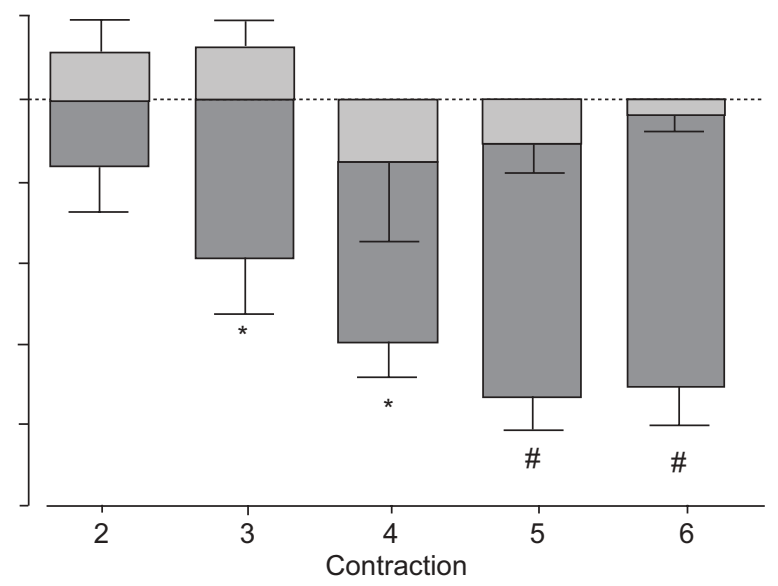

FIGURE 4. Representative $3 \times 10^{-7} \mathrm{M}$ acetylcholine (ACh; horizontal bars)-induced contractions of bovine airway smooth muscle (ASM) in the presence of KB-R7943 (- - - -). a) $10 \mu \mathrm{M}(\mathrm{n}=10)$ and b) $20 \mu \mathrm{M}(\mathrm{n}=7)$. ....... Magnitude of first contraction. c, d) Mean change in peak magnitude of these ACh-induced contractions ( $\square$ : $10 \mu \mathrm{M}$ KB-

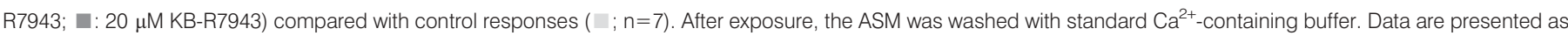
mean \pm SEM. *: $p<0.05 ;{ }^{*}: p<0.005$.

from which the SR can be appropriately refilled. The importance of $\mathrm{Ca}^{2+}$ influx in SR refilling is especially evident when tissues are repetitively stimulated in $\mathrm{Ca}^{2+}$-free bathing solutions. Under these conditions, successive agonist-induced contractions are almost abolished, but return to control levels following the reintroduction of extracellular $\mathrm{Ca}^{2+}$ (fig. 2).

Agonist stimulation of ASM triggers membrane depolarisation, primarily through the activation of $\mathrm{Ca}^{2+}$-dependent $\mathrm{Cl}^{-}$ channels. These responses have been characterised in various airway preparations $[1-3,22,23]$. Thus it is plausible that agonist-induced membrane depolarisation activates the $\mathrm{Ca}^{2+}$ influx pathways required for appropriate store-refilling. In order to probe the role of membrane depolarisation in storerefilling, tissues were treated with cromakalim $(30 \mu \mathrm{M})$, a compound that selectively activates $\mathrm{K}_{\mathrm{ATP}}$ [16]. Cromakalim is known to cause relaxation of many smooth muscle types, including ASM, and this effect is universally attributed to its action on glibenclamide-sensitive $\mathrm{K}_{\mathrm{ATP}}$ [24-27]. By triggering $\mathrm{K}^{+}$efflux via the $\mathrm{K}_{\mathrm{ATP}}$, cromakalim hyperpolarises the membrane potential towards the potassium equilibrium potential (i.e. $\sim 80 \mathrm{mV}$ ) [6]. Cromakalim treatment significantly reduced the magnitude of successive agonist-induced contractions (figs $3 a$ and $c$ ), an effect that was abolished in the presence of glibenclamide $(10 \mu \mathrm{M})$; a selective blocker of the $\mathrm{K}_{\text {ATP }}$ (figs $3 \mathrm{~b}$ and $\mathrm{d}$ ) [16].

The importance of this finding is three-fold. First, the effect of cromakalim was almost abolished in the presence of glibenclamide, a selective inhibitor of the $\mathrm{K}_{\mathrm{ATP}}$, supporting the selectivity of the intervention. Secondly, inhibition of membrane depolarisation through pre-treatment with cromakalim caused a graded reduction in the magnitude of successive contractions, suggesting a gradual reduction in SR refilling throughout the protocol, in response to inhibition of voltagedependent $\mathrm{Ca}^{2+}$ influx pathways. If voltage-dependent $\mathrm{Ca}^{2+}$ influx were directly involved in excitation-contraction coupling, cromakalim's effect would have been immediate. Instead the gradual and progressive reduction suggests that agonistinduced $\mathrm{Ca}^{2+}$ mobilisation is the primary mechanism driving $\mathrm{Ca}^{2+}$-dependent contraction, and that the SR is being refilled, in part, through voltage-dependent $\mathrm{Ca}^{2+}$-influx. Finally, these data call into question any major role of ROCs/SOCs in the store-refilling process in ASM. When examining the electrophysiological properties of NSCCs, the current-voltage relationship is such that the inward current is greatest under negative membrane potentials [14]. Thus $\mathrm{Ca}^{2+}$ influx through ROCs/ SOCs should be increased by membrane hyperpolarisation, 

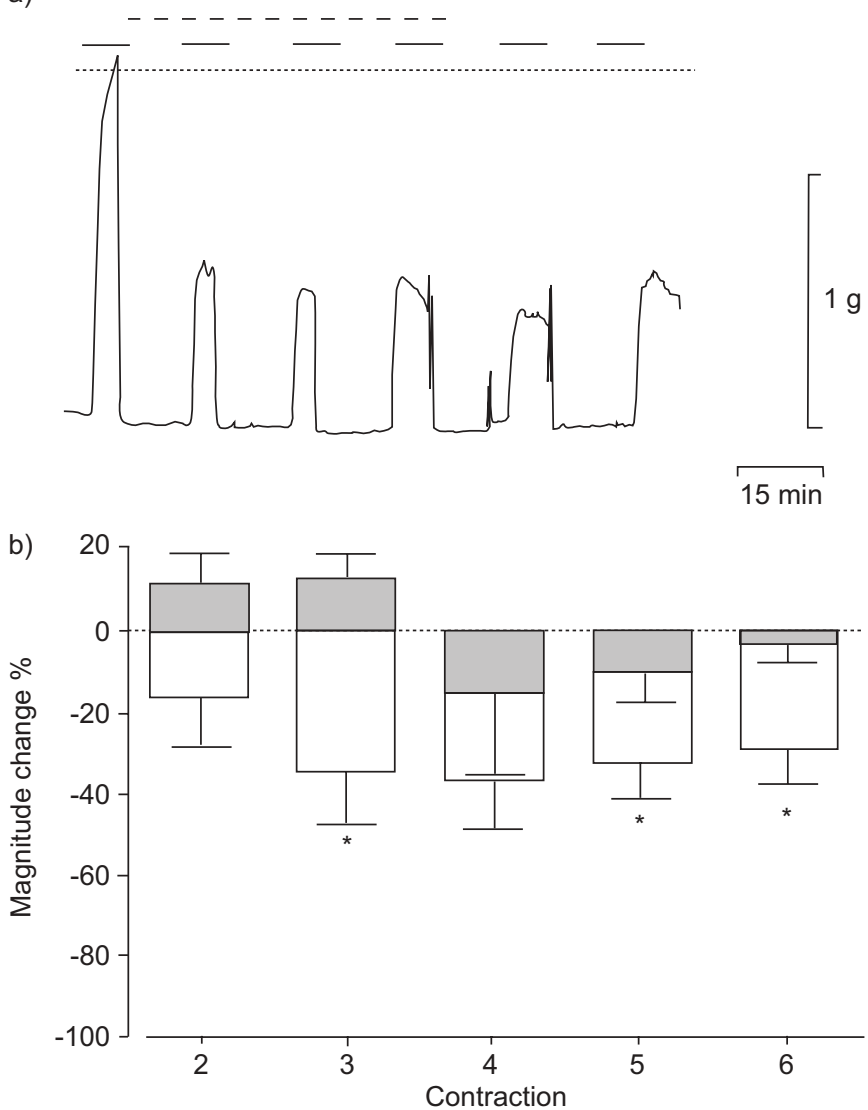

FIGURE 5. a) Representative $3 \times 10^{-7} \mathrm{M}$ acetylcholine (ACh; horizontal bars)induced contractions of bovine airway smooth muscle (ASM) in the presence of $1 \mu \mathrm{M}$ nifedipine (- - - -; n=6). .......: Magnitude of first contraction. b) Mean changes in peak magnitude of these ACh-induced contractions $(\square)$ compared with control responses $(\square ; n=10)$. After exposure, the ASM was washed with standard $\mathrm{Ca}^{2+}$ containing buffer. Data are presented as mean \pm SEM. *: $p<0.05$

or clamping in negative potentials, during cromakalim treatment. As such, any contribution of these channels to store-refilling should have been amplified by treatment with cromakalim. In contrast, the data suggest that store-refilling is dominated by voltage-dependent mechanisms, and that voltage-independent mechanisms, such as ROC/SOC currents, play only a minor role, if any.

Since it is apparent that voltage-dependent $\mathrm{Ca}^{2+}$ influx pathways play a role in store-refilling, successive agonist-induced contractions were examined in the presence of agents targeting the reverse-mode of the NCX and L-type $\mathrm{Ca}^{2+}$ channels, both voltage-regulated systems. KB-R7943 is a selective inhibitor of the NCX, and blocks the reverse-mode almost 60 times more strongly than the forward-mode [17-21]. When examining the pharmacology of KB-R7943, BRADLEY et al. [18] reported that it had no effect on the release of $\mathrm{Ca}^{2+}$ from the SR, and nor did it alter the inward current mediated by $\mathrm{Ca}^{2+}$-dependent $\mathrm{Cl}^{-}$ channels. Furthermore, KAWANO et al. [28] reported that high concentrations of KB-R7943 (30-100 $\mu \mathrm{M})$ reduced spontaneous $\mathrm{Ca}^{2+}$ oscillations in human mesenchymal stem cells, but had no effect on the lanthanum-sensitive component of these oscillations mediated by NSCCs. In intact tissue preparations, DAI et al. [7]
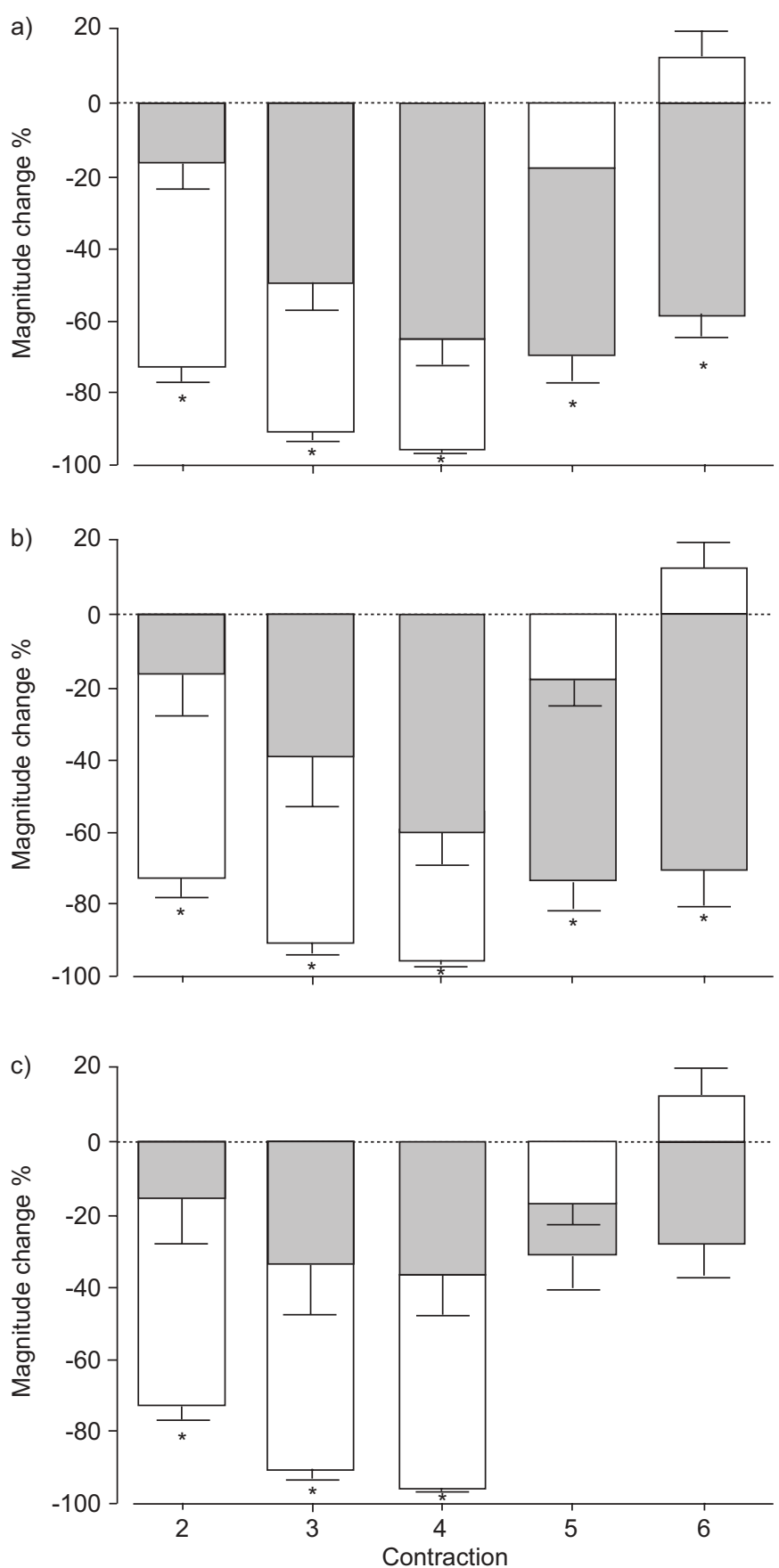

FIGURE 6. Mean changes in peak magnitudes of $3 \times 10^{-7} \mathrm{M}$ acetylcholine (ACh)-induced contractions in the presence ( $\square$ ) of: a) $10 \mu \mathrm{M} \mathrm{KB-R7943} \mathrm{(} n=10)$; b) $20 \mu \mathrm{M} \mathrm{KB}-\mathrm{R} 7943(\mathrm{n}=7)$; and c) $1 \mu \mathrm{M}$ nifedipine $(\mathrm{n}=6)$ compared with responses in the absence of extracellular $\mathrm{Ca}^{2+}(\square ; n=5)$. After exposure (contractions $\left.2-4\right)$, the ASM was washed with zero- $\mathrm{Ca}^{2+}$ buffer (contractions 5 and 6). Data are presented as mean \pm SEM. *: $p<0.05$.

reported that KB-R7943, at the concentration used in the present study, abolished agonist-induced asynchronous $\mathrm{Ca}^{2+}$ oscillations, an effect attributed to inhibition of $\mathrm{Ca}^{2+}$ influx via the reverse-mode of the NCX. More recently, DAI et al. [29] used KB-R7943 to identify a role for the reverse-mode of the NCX in the agonist-induced asynchronous $\mathrm{Ca}^{2+}$ oscillations observed in intact human ASM preparations. 
a)
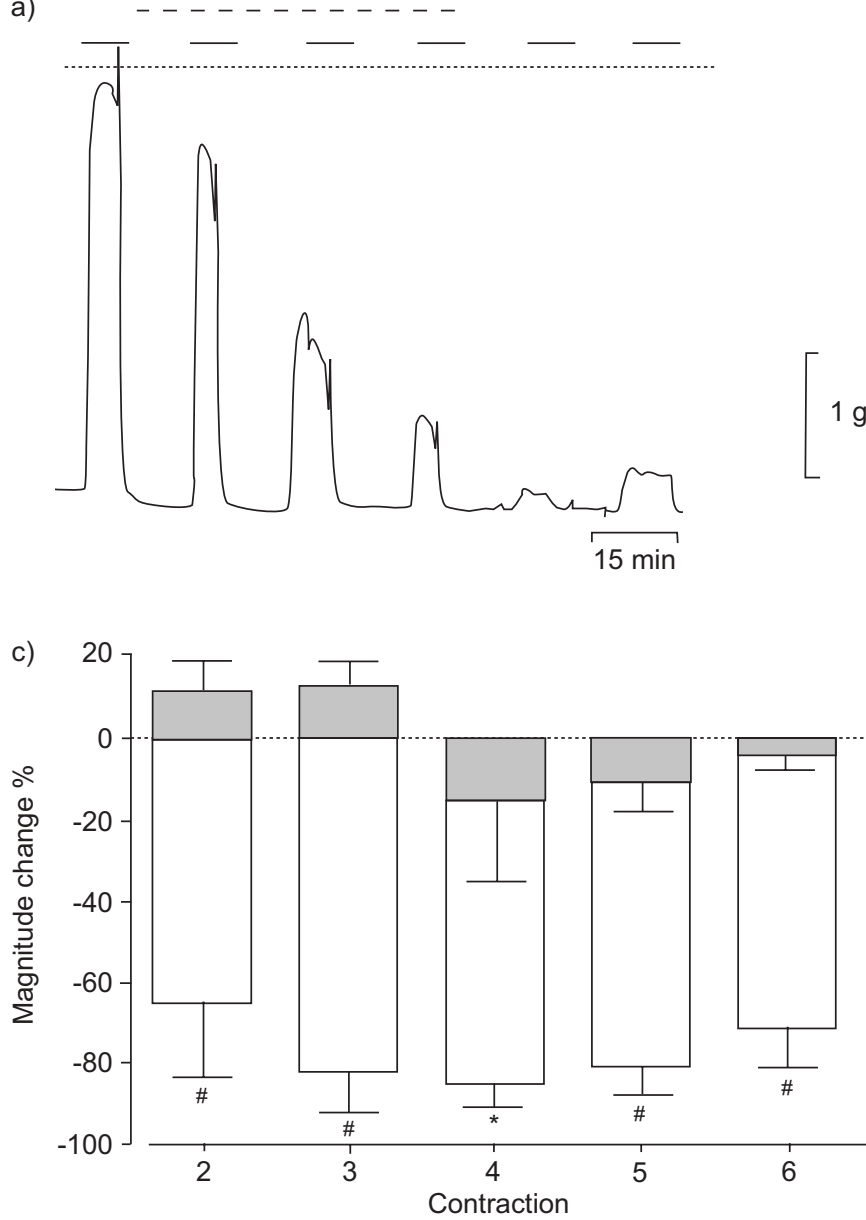

b)

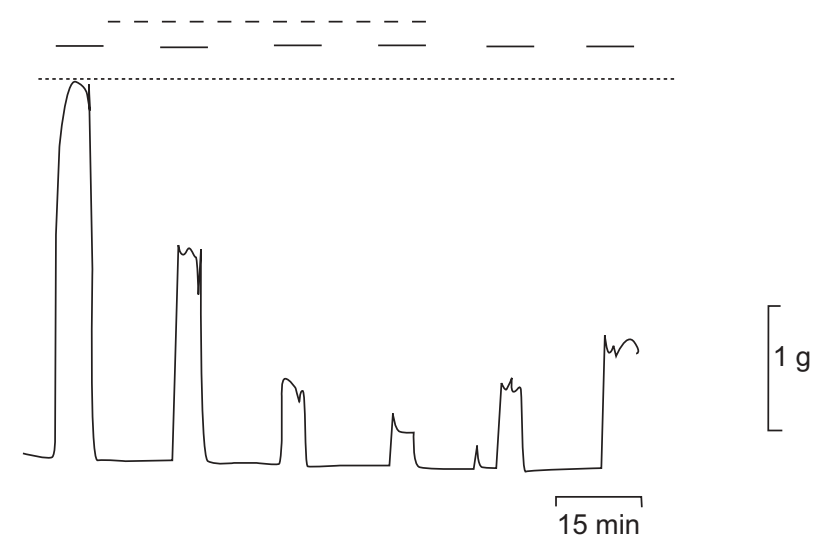

d)

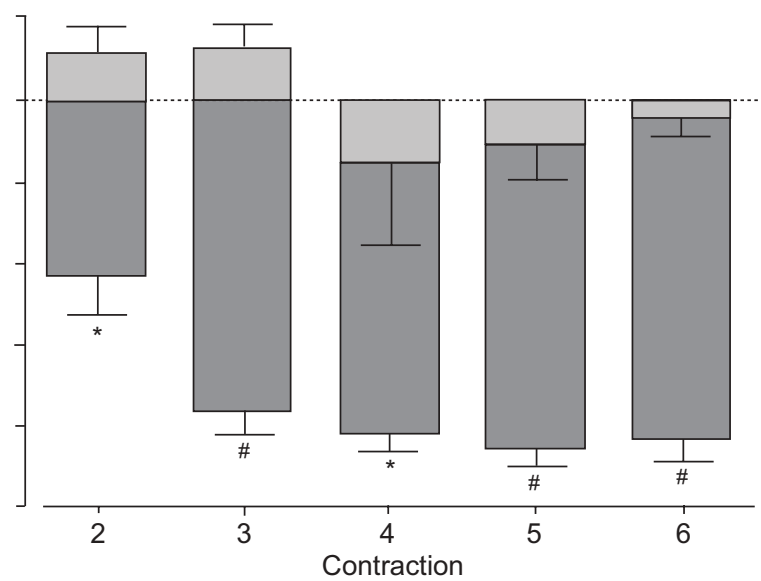

FIGURE 7. Representative $3 \times 10^{-7} \mathrm{M}$ acetylcholine (ACh; horizontal bars)-induced contractions of bovine airway smooth muscle (ASM) during concurrent treatment with

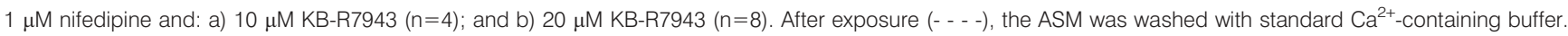
Magnitude of first contraction. c, d) Mean change in peak magnitude of these ACh-induced contractions ( $\square: 1 \mu \mathrm{M}$ nifedipine plus $10 \mu \mathrm{M}$ KB-R7943; $\square: 1 \mu \mathrm{M}$ nifedipine plus

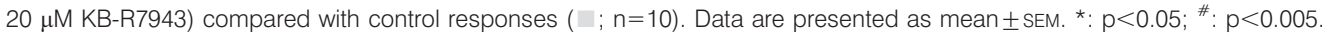

In the present study, both KB-R7943 and nifedipine, a prototypical L-type $\mathrm{Ca}^{2+}$ channel blocker, significantly reduced the magnitude of successive contractions (figs 4 and 5). However, neither KB-R7943 nor nifedipine alone reduced contractions to the extent observed in the absence of extracellular $\mathrm{Ca}^{2+}$ (fig. 6). Thus it seems that $\mathrm{Ca}^{2+}$ influx through both the NCX and L-type $\mathrm{Ca}^{2+}$ channels is necessary for complete refilling of the intracellular $\mathrm{Ca}^{2+}$ pool; concurrent treatment with both KB-R7943 and nifedipine displayed an additive effect in terms of reducing the magnitude of successive agonist-induced contractions (fig. 7). Indeed, simultaneous inhibition of the reverse-mode of the NCX and L-type $\mathrm{Ca}^{2+}$ channels practically abolished successive agonist-induced contractions, similar to the effect observed when tissues were bathed in $\mathrm{Ca}^{2+}$-free buffering solution (fig. 8).

In addition to pharmacological interventions, the removal of extracellular $\mathrm{Na}^{+}$from buffering solutions can gradually inhibit the NCX. This approach was utilised to probe the role of the NCX in store-refilling following agonist-induced $\mathrm{Ca}^{2+}$ mobilisation [13]. In the present study, removal of extracellular $\mathrm{Na}^{+}$in the presence of nifedipine (to inhibit L-type $\mathrm{Ca}^{2+}$ channels) led to a significant reduction in the magnitude of successive responses, similar to that observed during treatment with KB-R7943 (figs 9a and b). However, the reduction in magnitude observed during concurrent zero $\mathrm{Na}^{+}$and nifedipine treatment was not as great as that observed under zero $\mathrm{Ca}^{2+}$ conditions (fig. 9d). This may reflect the nature of this intervention; its effect is reliant upon the gradual depletion of intracellular $\mathrm{Na}^{+}$throughout the series of successive responses. Inhibition of the NCX occurs when the intracellular $\mathrm{Na}^{+}$ concentration is depleted, which is a gradual rather than immediate event. In contrast, pharmacological inhibition of the NCX is a more immediate event since it is dependent upon the direct interaction of KB-R7943 with the exchanger [19]. Interestingly, $\mathrm{Na}^{+}$depletion, in the presence of nifedipine, decreased responses beyond those observed during nifedipine treatment alone (fig. 9c). This observation highlights the existence of a $\mathrm{Na}^{+}$-dependent $\mathrm{Ca}^{2+}$ influx pathway (i.e. the reverse-mode of the NCX), which plays a role in store-refilling following agonist-induced $\mathrm{Ca}^{2+}$ mobilisation.

In addition to the functional identification of a $\mathrm{Ca}^{2+}$-influx pathway mediated through the reverse-mode activity of the 


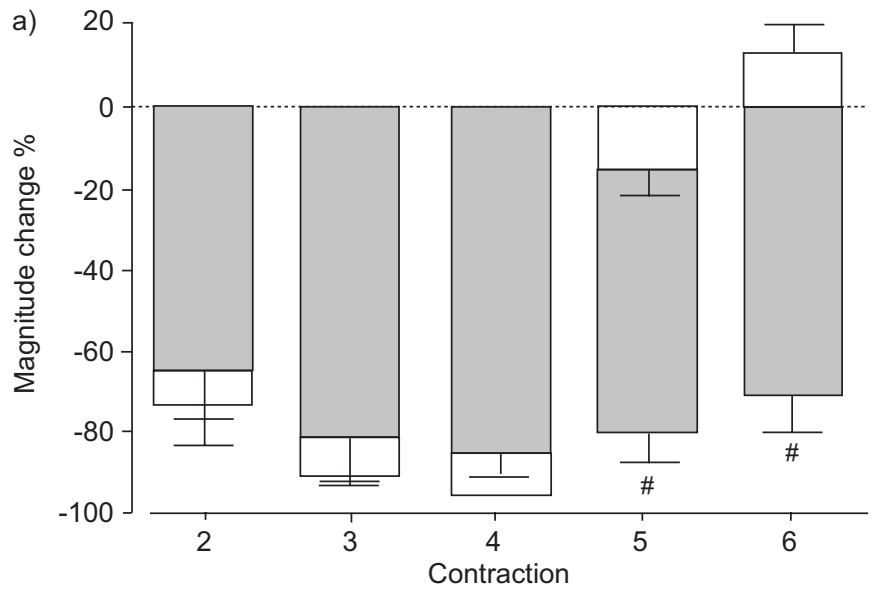

b)

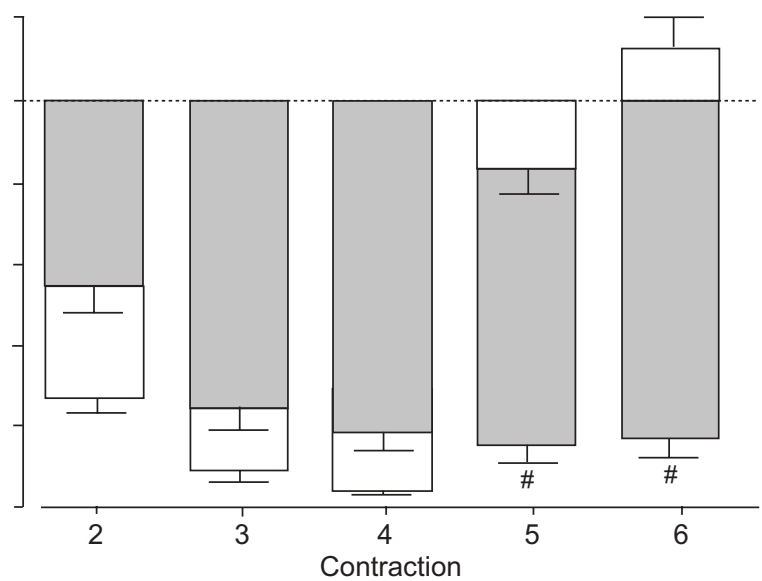

FIGURE 8. Mean changes in peak magnitudes of $3 \times 10^{-7} \mathrm{M}$ acetylcholine (ACh)-induced contractions in the presence ( $\square$ ) of $1 \mu \mathrm{M}$ nifedipine plus: a) $10 \mu \mathrm{M}$ KB-R7943 $(n=4)$ and b) $20 \mu \mathrm{M} \mathrm{KB}-\mathrm{R} 7943(\mathrm{n}=8)$ compared with responses in the absence of extracellular $\mathrm{Ca}^{2+}(\square ; n=5)$. After exposure (contractions $\left.2-4\right)$, the ASM was washed with zero-Ca ${ }^{2+}$ buffer (contractions 5 and 6). Data are presented as mean \pm SEM. ${ }^{\#}: p<0.005$.

NCX, protein expression was probed in bovine tracheal smooth muscle samples. Three major isoforms of the NCX exist: NCX1, NCX2 and NCX3 [12, 30]. NCX2 and NCX3 expression are mainly limited to the brain and skeletal muscle $[12,31-33]$, whereas NCX1 displays a more profuse expression profile $[12,34]$. In addition to this major classification, the a)
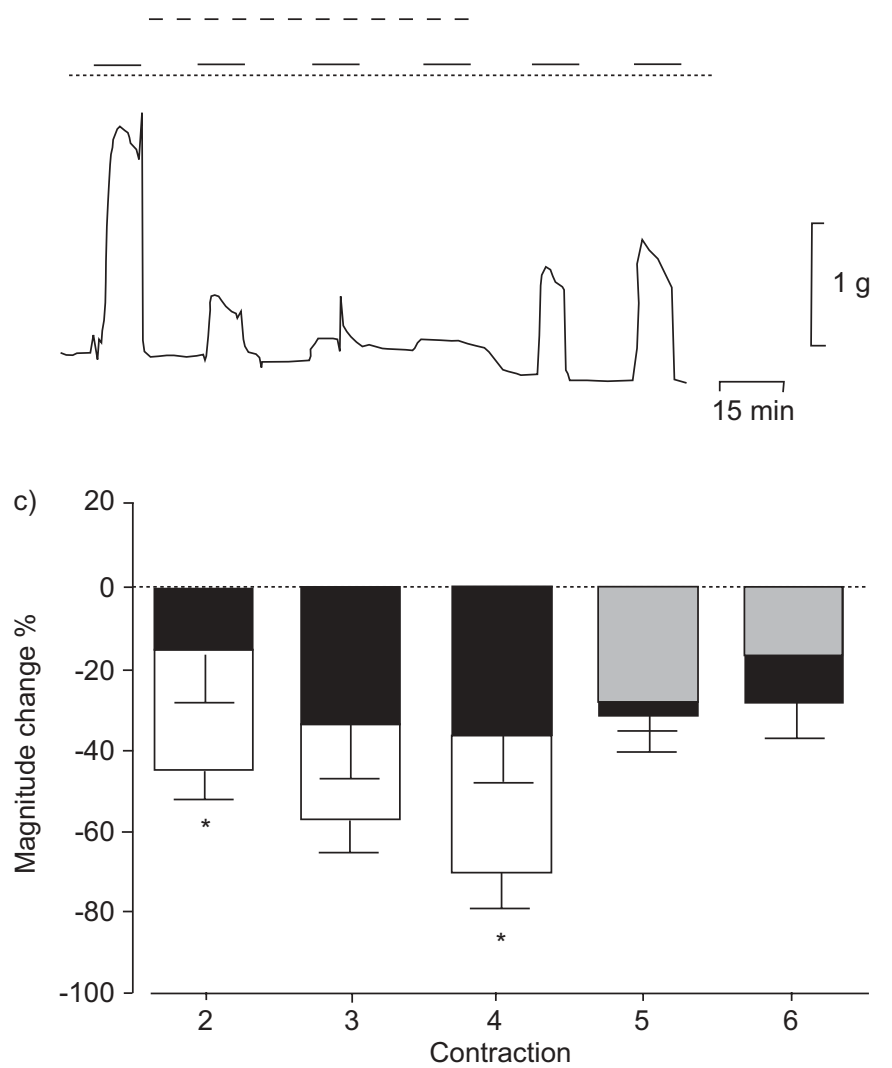

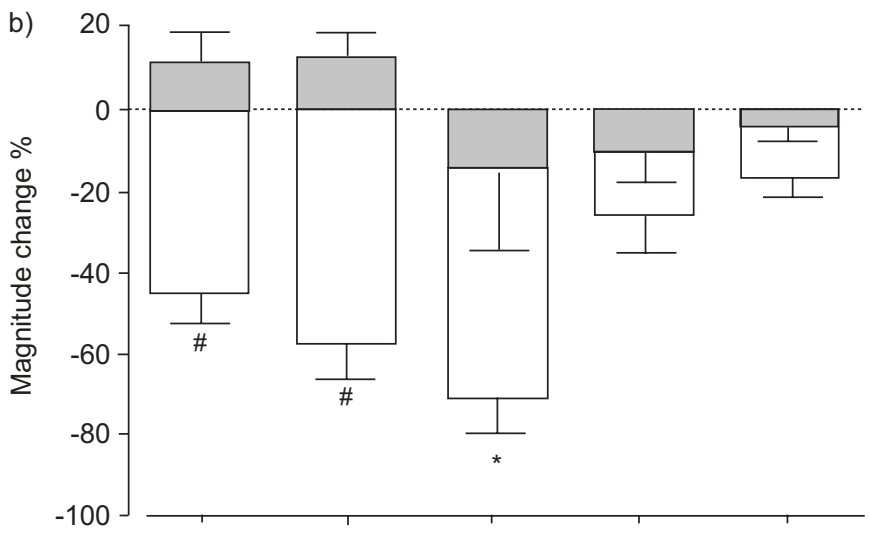

d)

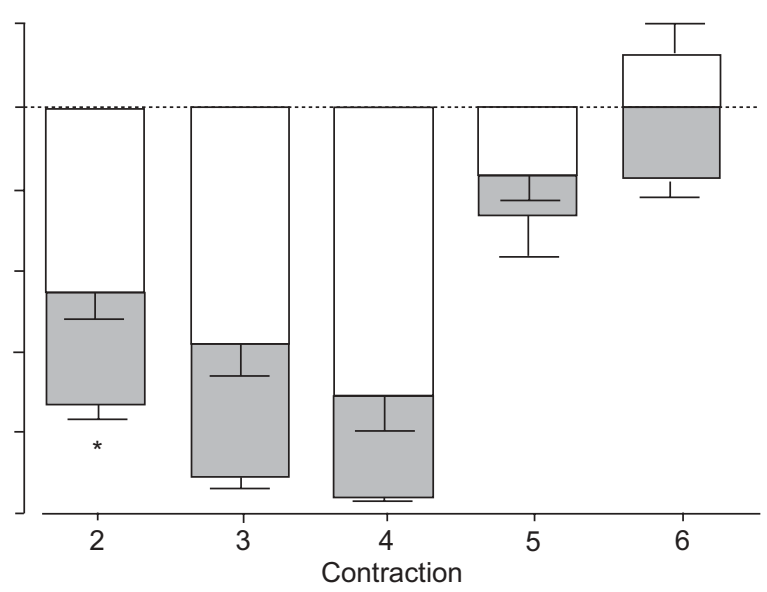

FIGURE 9. a) Representative $3 \times 10^{-7} \mathrm{M}$ acetylcholine (ACh; horizontal bars)-induced contractions of bovine airway smooth muscle (ASM) during concurrent treatment with $1 \mu \mathrm{M}$ nifedipine and zero-Na ${ }^{+}$buffer (- - - -; $\left.\mathrm{n}=5\right)$. ........: Magnitude of first contraction. b-d) Mean changes in peak magnitude of these ACh-induced contractions in the presence of $1 \mu \mathrm{M}$ nifedipine and zero-Na ${ }^{+}$buffer $(\square)$ compared with b) control responses ( $\left.\square ; n=10\right)$; c) nifedipine treatment alone $(\square ; n=6)$; and d) zero-Ca ${ }^{2+}$ conditions $(\square ; n=5)$. After exposure (contractions 2-4), the ASM was washed with fresh buffer (contractions 5 and 6 ). Data are presented as mean \pm SEM. ${ }^{*}: p<0.05 ;{ }^{*}: p<0.005$. 


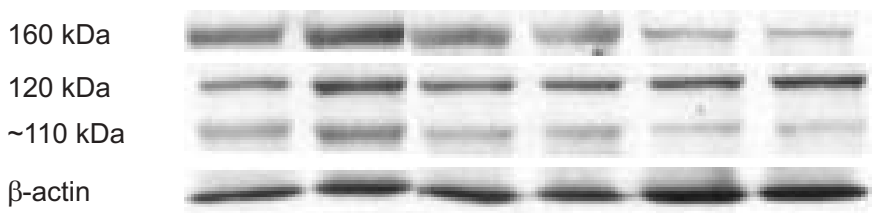

FIGURE 10. Western blot detection of sodium-calcium exchanger (NCX) isoform 1, performed in protein extracts isolated from bovine tracheal smooth muscle cells, indicating expression of NCX1.1 ( 120 kDa) and NCX1.3 $(\sim 110 \mathrm{kDa})$. Each lane represents a protein isolate from a different animal.

NCX1 isoform can be expressed as a variety of splice variants which determine variable properties in terms of ionic sensitivity and regulation by intracellular processes [35-39]. When probing the present preparation for NCX1, three major bands corresponding to molecular masses of 160, 120 and $110 \mathrm{kDa}$ were observed. The 160-kDa band has been reported in cases in which the reducing agents have insufficiently altered the protein structure prior to separation $[39,40]$. The $120-\mathrm{kDa}$ band corresponds to the unspliced NCX1.1 isoform reported in a number of different systems [12, 30, 36, 39, 40]. Alternative splicing of an intracellular loop of NCX1 can lead to a number of smaller isoforms $[12,30]$. Indeed a band of $\sim 110 \mathrm{kDa}$, which corresponds to the theoretical and reported size of the NCX1.3 isoform, was identified [12, 36, 41]. Interestingly, the NCX1.3 isoform has been associated with the aberrant $\mathrm{Ca}^{2+}$ influx observed in salt-dependent hypertension $[37,38,42]$.

Taken together, the present data suggest that previous reports examining the role of voltage-dependent calcium ion influx in store-refilling may have overlooked the contribution of the reverse-mode of the sodium-calcium exchanger. It is apparent that inhibition of L-type calcium channels alone does not completely abolish successive agonist-induced contractions of airway smooth muscle. Indeed, this approach has failed in the clinical setting, whereby dihydropyridine compounds were proven ineffective in the management of obstructive airway diseases, such as asthma [43-45]. However, treatment aimed at inhibiting both L-type calcium channels and the reverse-mode of the sodium-calcium exchanger in airway smooth muscle may prove effective at reversing the increased contractile tone associated with airway obstruction. Interestingly, inhibition of the sodium-calcium exchanger is currently touted as a potential clinical strategy for treating hypertensive conditions associated with increased calcium ion influx through the reverse-mode of the sodium-calcium exchanger [37, 38, 42, 46, 47]. It is apparent that further in vivo study is required in order to determine whether or not the sodium-calcium exchanger plays a role in obstructive airway disease. Furthermore, animal models of airway hyperresponsiveness may prove the ideal setting in which to determine what effect concurrent inhibition of the reverse-mode of the sodium-calcium exchanger and L-type calcium channels might have on the airway hyperresponsiveness and reduced airway calibre associated with asthma.

\section{REFERENCES}

1 Janssen LJ, Sims SM. Emptying and refilling of $\mathrm{Ca}^{2+}$ store in tracheal myocytes as indicated by ACh-evoked currents and contraction. Am J Physiol 1993; 265: C877-C886.
2 Janssen LJ, Sims SM. Spontaneous transient inward currents and rhythmicity in canine and guinea-pig tracheal smooth muscle cells. Pflugers Arch 1994; 427: 473-480.

3 Janssen LJ, Sims SM. $\mathrm{Ca}^{2+}$-dependent $\mathrm{Cl}^{-}$current in canine tracheal smooth muscle cells. Am J Physiol 1995; 269: C163-C169.

4 Bourreau JP, Kwan CY, Daniel EE. Excitation-contraction coupling in canine tracheal smooth muscle cells. Adv Exp Med Biol 1992; 311: 375-377.

5 Bourreau J, Abela A, Kwan C, Daniel E. Acetylcholine Ca ${ }^{2+}$ stores refilling directly involves a dihydropyrodine-sensitive channel in dog trachea. Am J Physiol 1991; 261: C496-C505.

6 Bourreau J, Kwan C, Daniel E. Distinct pathways to refill ACh-sensitive internal $\mathrm{Ca}^{2+}$ stores in canine airway smooth muscle. Am J Physiol 1993; 265: C28-C35.

7 Dai JM, Kuo KH, Leo JM, van Breemen C, Lee $\mathrm{CH}$. Mechanism of ACh-induced asynchronous calcium waves and tonic contraction in porcine tracheal muscle bundle. Am J Physiol Lung Cell Mol Physiol 2006; 290: L459-L469.

8 Lemos VS, Poburko D, Liao CH, Cole WC, van Breemen C. $\mathrm{Na}^{+}$entry via TRPC6 causes $\mathrm{Ca}^{2+}$ entry via NCX reversal in ATP stimulated smooth muscle cells. Biochem Biophys Res Commun 2007; 352: 130-134.

9 Poburko D, Kuo KH, Dai J, Lee CH, van Breemen C. Organellar junctions promote targeted $\mathrm{Ca}^{2+}$ signaling in smooth muscle: why two membranes are better than one. Trends Pharmacol Sci 2004; 25: 8-15.

10 Poburko D, Potter K, van Breemen E, et al. Mitochondria buffer NCX-mediated $\mathrm{Ca}^{2+}$-entry and limit its diffusion into vascular smooth muscle cells. Cell Calcium 2006; 40: 359-371.

$11 \mathrm{Wu} \mathrm{C}$, Fry $\mathrm{CH}$. $\mathrm{Na}^{+} / \mathrm{Ca}^{2+}$ exchange and its role in intracellular $\mathrm{Ca}^{2+}$ regulation in guinea pig detrusor smooth muscle. Am J Physiol Cell Physiol 2001; 280: C1090-C1096.

12 Blaustein MP, Lederer WJ. Sodium/calcium exchange: its physiological implications. Physiol Rev 1999; 79: 763-854.

13 Hirota S, Pertens E, Janssen LJ. The reverse mode of the $\mathrm{Na}^{+} / \mathrm{Ca}^{2+}$ exchanger provides a source of $\mathrm{Ca}^{2+}$ for store refilling following agonist-induced $\mathrm{Ca}^{2+}$ mobilization. Am J Physiol Lung Cell Mol Physiol 2007; 292: L438-L447.

14 Helli PB, Pertens E, Janssen LJ. Cyclopiazonic acid activates a $\mathrm{Ca}^{2+}$-permeable, nonselective cation conductance in porcine and bovine tracheal smooth muscle. J Appl Physiol 2005; 99: 1759-1768.

15 Hirota S, Trimble N, Pertens E, Janssen LJ. Intracellular $\mathrm{Cl}^{-}$ fluxes play a novel role in $\mathrm{Ca}^{2+}$ handling in airway smooth muscle. Am J Physiol Lung Cell Mol Physiol 2006; 290: L1146-L1153.

16 Quayle JM, Nelson MT, Standen NB. ATP-sensitive and inwardly rectifying potassium channels in smooth muscle. Physiol Rev 1997; 77: 1165-1232.

17 Birinyi P, Acsai K, Banyasz T, et al. Effects of SEA0400 and KB-R7943 on $\mathrm{Na}^{+} / \mathrm{Ca}^{2+}$ exchange current and L-type $\mathrm{Ca}^{2+}$ current in canine ventricular cardiomyocytes. Naunyn Schmiedebergs Arch Pharmacol 2005; 372: 63-70.

18 Bradley E, Hollywood MA, Johnston L, et al. Contribution of reverse $\mathrm{Na}^{+} / \mathrm{Ca}^{2+}$ exchange to spontaneous activity in interstitial cells of Cajal in the rabbit urethra. J Physiol 2006; 574: 651-661.

19 Iwamoto T, Kita S. Development and application of $\mathrm{Na}^{+} /$ $\mathrm{Ca}^{2+}$ exchange inhibitors. Mol Cell Biochem 2004; 259: 157-161. 
20 Takai N, Yamada A, Muraki K, Watanabe M, Imaizumi Y. KB-R7943 reveals possible involvement of $\mathrm{Na}^{+}-\mathrm{Ca}^{2+}$ exchanger in elevation of intracellular $\mathrm{Ca}^{2+}$ in rat carotid arterial myocytes. J Smooth Muscle Res 2004; 40: 35-42.

21 Watano T, Kimura J, Morita T, Nakanishi H. A novel antagonist, No. 7943, of the $\mathrm{Na}^{+} / \mathrm{Ca}^{2+}$ exchange current in guinea-pig cardiac ventricular cells. Br J Pharmacol 1996; 119: 555-563.

22 Janssen L. Acetylcholine and caffeine activate $\mathrm{Cl}^{-}$and suppress $\mathrm{K}^{+}$conductances in human bronchial smooth muscle. Am J Physiol 1996; 270: L772-L781.

23 Kotlikoff MI, Wang YX. Calcium release and calciumactivated chloride channels in airway smooth muscle cells. Am J Respir Crit Care Med 1998; 158: S109-S114.

24 Buckle DR, Arch JR, Bowring NE, et al. Relaxant effects of the potassium channel activators BRL 38227 and pinacidil on guinea-pig and human airway smooth muscle, and blockade of their effects by glibenclamide and BRL 31660 . Pulm Pharmacol 1993; 6: 77-86.

25 Cortijo J, Sarria B, Pedros C, Perpina M, Paris F, Morcillo E. The relaxant effects of cromakalim (BRL 34915) on human isolated airway smooth muscle. Naunyn Schmiedebergs Arch Pharmacol 1992; 346: 462-468.

26 Nielsen-Kudsk JE. Potassium channel modulation: a new drug principle for regulation of smooth muscle contractility. Studies on isolated airways and arteries. Dan Med Bull 1996; 43: 429-447.

27 Raeburn D, Brown TJ. RP 49356 and cromakalim relax airway smooth muscle in vitro by opening a sulphonylurea-sensitive $\mathrm{K}^{+}$channel: a comparison with nifedipine. J Pharmacol Exp Ther 1991; 256: 480-485.

28 Kawano S, Otsu K, Shoji S, Yamagata K, Hiraoka M. Ca ${ }^{2+}$ oscillations regulated by $\mathrm{Na}^{+}-\mathrm{Ca}^{2+}$ exchanger and plasma membrane $\mathrm{Ca}^{2+}$ pump induce fluctuations of membrane currents and potentials in human mesenchymal stem cells. Cell Calcium 2003; 34: 145-156.

29 Dai JM, Kuo KH, Leo JM, Pare PD, van Breemen C, Lee CH. Acetylcholine-induced asynchronous calcium waves in intact human bronchial muscle bundle. Am J Respir Cell Mol Biol 2007; 36: 600-608.

30 Philipson KD, Nicoll DA. Sodium-calcium exchange: a molecular perspective. Annu Rev Physiol 2000; 62: 111-133.

31 Li Z, Matsuoka S, Hryshko LV, et al. Cloning of the NCX2 isoform of the plasma membrane $\mathrm{Na}^{+}-\mathrm{Ca}^{2+}$ exchanger. J Biol Chem 1994; 269: 17434-17439.

32 Linck B, Qiu Z, He Z, Tong Q, Hilgemann DW, Philipson KD. Functional comparison of the three isoforms of the $\mathrm{Na}^{+} / \mathrm{Ca}^{2+}$ exchanger (NCX1, NCX2, NCX3). Am J Physiol 1998; 274: C415-C423.

33 Nicoll DA, Quednau BD, Qui Z, Xia YR, Lusis AJ, Philipson KD. Cloning of a third mammalian $\mathrm{Na}^{+}-\mathrm{Ca}^{2+}$ exchanger, NCX3. J Biol Chem 1996; 271: 24914-24921.
34 Quednau BD, Nicoll DA, Philipson KD. Tissue specificity and alternative splicing of the $\mathrm{Na}^{+} / \mathrm{Ca}^{2+}$ exchanger isoforms NCX1, NCX2, and NCX3 in rat. Am J Physiol 1997; 272: C1250-C1261.

35 Ander BP, Hurtado C, Raposo CS, et al. Differential sensitivities of the NCX1.1 and NCX1.3 isoforms of the $\mathrm{Na}^{+}-\mathrm{Ca}^{2+}$ exchanger to $\alpha$-linolenic acid. Cardiovasc Res 2007; 73: 395-403.

36 Hurtado C, Prociuk M, Maddaford TG, et al. Cells expressing unique $\mathrm{Na}^{+} / \mathrm{Ca}^{2+}$ exchange (NCX1) splice variants exhibit different susceptibilities to $\mathrm{Ca}^{2+}$ overload. Am J Physiol Heart Circ Physiol 2006; 290: H2155-H2162.

37 Iwamoto T, Kita S, Katsuragi T. Salt-sensitive hypertension, $\mathrm{Na}^{+} / \mathrm{Ca}^{2+}$ exchanger, and vascular smooth muscle. Trends Cardiovasc Med 2005; 15: 273-277.

38 Iwamoto T, Kita S, Zhang J, et al. Salt-sensitive hypertension is triggered by $\mathrm{Ca}^{2+}$ entry via $\mathrm{Na}^{+} / \mathrm{Ca}^{2+}$ exchanger type-1 in vascular smooth muscle. Nat Med 2004; 10: 1193-1199.

39 Van Eylen F, Kamagate A, Herchuelz A. Characterization and functional activity of a truncated $\mathrm{Na} / \mathrm{Ca}$ exchange isoform resulting from a new splicing pattern of NCX1. Ann N Y Acad Sci 2002; 976: 81-84.

40 Philipson KD, Longoni S, Ward R. Purification of the cardiac $\mathrm{Na}^{+}-\mathrm{Ca}^{2+}$ exchange protein. Biochim Biophys Acta 1988; 945: 298-306.

41 Nicoll DA, Longoni S, Philipson KD. Molecular cloning and functional expression of the cardiac sarcolemmal $\mathrm{Na}^{+}-$ $\mathrm{Ca}^{2+}$ exchanger. Science 1990; 250: 562-565.

42 Iwamoto T. Vascular $\mathrm{Na}^{+} / \mathrm{Ca}^{2+}$ exchanger: implications for the pathogenesis and therapy of salt-dependent hypertension. Am J Physiol Regul Integr Comp Physiol 2006; 290: R536-R545.

43 Fish J. Calcium channel antagonists in the treatment of asthma. J Asthma 1984; 21: 407-418.

44 Gordon EH, Wong SC, Klaustermeyer WB. Comparison of nifedipine with a new calcium channel blocker, flordipine, in exercise-induced asthma. J Asthma 1987; 24: 261-265.

45 Hoppe M, Harman E, Hendeles L. The effect of inhaled gallopamil, a potent calcium channel blocker, on the latephase response in subjects with allergic asthma. J Allergy Clin Immunol 1992; 89: 688-695.

46 Yu Y, Fantozzi I, Remillard CV, et al. Enhanced expression of transient receptor potential channels in idiopathic pulmonary arterial hypertension. Proc Natl Acad Sci USA 2004; 101: 13861-13866.

47 Zhang S, Dong H, Rubin LJ, Yuan JX. Upregulation of $\mathrm{Na}^{+} / \mathrm{Ca}^{2+}$ exchanger contributes to the enhanced $\mathrm{Ca}^{2+}$ entry in pulmonary artery SMC from patients with IPAH. Am J Physiol Cell Physiol 2006; [Epub ahead of print PMID: 17192285]. 